\title{
A Comprehensive Approach to Thyroid Swellings: Clinical, Sonological, Cytological and Histopathological Correlation
}

\author{
${ }^{1}$ UP Santosh, ${ }^{2} \mathrm{~KB}$ Sunil Kumar, ${ }^{3} \mathrm{MC}$ Trupthi, ${ }^{4} \mathrm{~S}$ Boobalan
}

\section{ABSTRACT}

Objectives: This study was conducted with the aim of clinicopathological evaluation of thyroid swellings.

Setting: Tertiary referral centre, Davangere, Karnataka, India. Design: Retrospective study.

Materials and methods: Clinical details, sonological reports, laboratory reports were retrieved from the records for the 110 patients with thyroid swellings who were included in our study, between May 2009 and April 2013 and the data was analyzed. Cytological smears in all patients and histopathology slides in operated patients were retrieved and studied.

Results: The highest incidence $(37.4 \%)$ of thyroid swellings were found in age group of 21 to 30 years. The youngest patient being 10 years. Females (90\%) predominated in this study, male to female ratio being 1:9. Majority of patients $(35 \%)$ came with complaints of swelling of duration less than 6 months. Among 110 patients, $36.36 \%$ of them were treated conservatively, out of which 7 cases (17.5\%) were hyperthyroid, 10 cases $(25 \%)$ were hypothyroid and 23 cases $(57.5 \%)$ were euthyroid and the remaining $63.63 \%$ of them underwent surgery. Of the 110 patients subjected to FNAC, 16 patients (14.54\%) were neoplastic and 94 patients (85.45\%) were non-neoplastic. Upon correlation with the histopathology report, the sensitivity of FNAC was $78.57 \%$, specificity was $91.07 \%$, with a positive predictive value of $68.75 \%$ and negative predictive value of $94.44 \%$. Diagnostic accuracy of FNAC is $88.50 \%$.

Conclusion: FNAC and USG are valuable tools in assessing the need for surgical intervention in thyroid swellings. USG guided aspiration will further enhance the cytological yield and diagnostic accuracy.

Keywords: Thyroid, USG, Cytology, Histopathology.

How to cite this article: Santosh UP, Sunil Kumar KB, Trupthi MC, Boobalan S. A Comprehensive Approach to Thyroid Swellings: Clinical, Sonological, Cytological and Histopathological Correlation. Int J Otorhinolaryngol Clin 2014;6(1):5-8.

Source of support: Nil

Conflict of interest: None

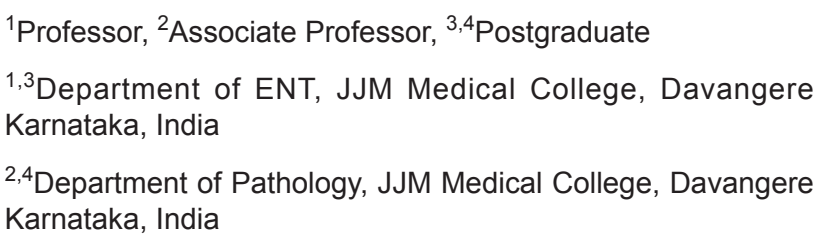

Corresponding Author: UP Santosh, Professor, Department of ENT, JJM Medical College, Davangere, Karnataka, India Phone: 9845155223, e-mail: drsantoshup@gmail.com

\section{INTRODUCTION}

The pathobiology of thyroid tumor is of special interest both because of the unique nature of thyroid gland and its lesions and also because of their impact on other tissues.

The thyroid can be afflicted by various diseases of endocrine, inflammatory or neoplastic nature and are commonly encountered in clinical practice with an incidence of 4 to $7 \%$, but this percentage may increase on ultrasonography. ${ }^{1}$ Thyroid swellings are four times more common in females than in males, nodular goiter being the most common cause. Nodular thyroid is a diagnostic enigma for the clinician in view of the fact that a few of the nodules are malignant. ${ }^{2}$

Although most isolated thyroid swellings are benign, it is difficult to exclude malignancy without excision and histological examination. Cytological studies (fine needle aspiration cytology and imprint cytology) are more sensitive than sonological studies in differentiating neoplastic and non neoplastic lesions and are presently valuable adjuncts to preoperative screening in the diagnosis of thyroid nodule.

\section{MATERIALS AND METHODS}

This is a retrospective study conducted in Chigateri General Hospital and Bapuji Hospital (teaching hospitals), attached to JJM Medical College, Davangere, Karnataka, India. Clinical details, sonological reports, laboratory reports and cytological reports were retrieved from the records for the 110 patients with thyroid swellings between May 2009 and April 2013 and the data was analyzed. For those patients who underwent aspiration cytology/surgery, slides and blocks was retrieved and examined.

\section{OBSERVATION AND RESULTS}

The age of patients in this study group ranged from 10 to 64 years and majority of cases were seen in second to third decades (37.3\%). Female patients formed $90 \%$ of the study group (M:F =1:9) as shown in Table 1.

The commonest symptom among the patients in our study group was swelling in front of the neck, the duration of which varied from 3 months to 7 years as follows: $<6$ months, $-35 \%, 6$ months to 1 year, $-28.3 \%, 1$ to 2 years, $-13 \%, 2$ to 5 years, $-13 \%$ and $>5$ years, $-10 \%$. 
Table 1: Age distribution

\begin{tabular}{lll}
\hline Age groups (yrs) & Number of cases & Percentage \\
\hline$<10$ & 2 & 1.8 \\
$11-20$ & 11 & 10 \\
$21-30$ & 41 & 37.3 \\
$31-40$ & 31 & 28.2 \\
$41-50$ & 17 & 15.45 \\
$51-60$ & 6 & 5.4 \\
$>60$ & 2 & 1.8 \\
\hline
\end{tabular}

Multinodular thyroid swelling (58 patients/52.72\%) was the commonest type of swelling, which was followed by diffuse swelling (39 patients/35.45\%), diffuse irregular swelling suspicious of malignancy ( 7 patients $/ 6.63 \%$ ) and lastly solitary thyroid nodule (6 patients/5.4\%). Less commonly associated symptoms such as pain in the swelling, change in voice and difficulty in swallowing were present $(10 \%)$.

All the 110 patients in our study group underwent thyroid function tests, ultrasonographic scan and blind fine needle aspiration cytology and 70 patients underwent surgery.

Ultrasonography was done in all cases to determine features suggestive of malignancy and extension into the neck in the case of thyroid cancer.

Most of the patients in our study group were euthyroid (93 patients/84.54\%), others were hypothyroid (10 patients/ $9 \%$ ) and remaining hyperthyroid (7 patients/6.3\%). Both hyperthyroid and hypothyroid patients were treated conservatively with tablet Carbimazole and tablet Thyroxin respectively. These patients were followed up till they were euthyroid and/or till the swelling regressed in size clinically. (Fig. 1).
The cytological and histological findings in patients with satisfactory aspirates who underwent surgery (70 patients) are compared in Table 2.

The accuracy of FNAC was analyzed, first for the detection of malignancy and second for the detection of neoplasia (Table 3).

Hence, in our study, taking histopathology as the gold standard for diagnosis, Sensitivity of FNAC was $78.5 \%$, specificity was $91.07 \%$, Positive predictive value was $68.75 \%$, Negative predictive value was $94.44 \%$ and diagnostic accuracy of FNAC was $88.50 \%$.

\section{DISCUSSION}

Thyroid enlargement, whether diffuse or nodular, leads to a battery of investigations like fine needle aspiration cytology, ultrasonography, thyroid function tests and thyroid scan, with an aim to select the patients who require surgery and those that can be managed conservatively. ${ }^{3}$

Absence of predominant symptoms attributable to thyroid in our study may be because of early report to hospital for treatment.

Hashimoto's thyroiditis is the most common cause of goitrous hypothyroidism among adults and is mostly seen around second to fourth decade in this study. Both sonography and FNAC are very helpful in diagnosing Hashimoto's thyroiditis. Sometimes a Hürthle cell predominant aspirate in lymphocytic thyroiditis can mimic Hürthle cell neoplasm.

Most thyroid swellings are benign but it is difficult to exclude malignancy without excision and histological examination. Overall, the incidence of thyroid malignancy

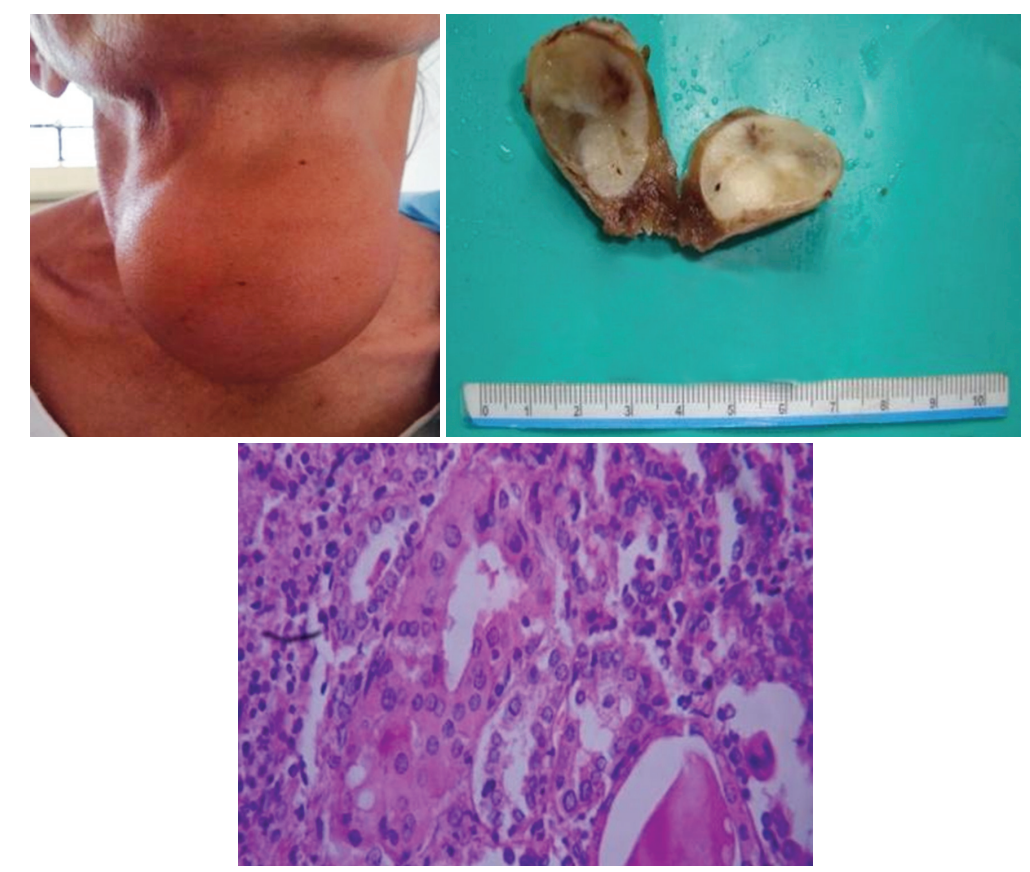

Fig. 1: A case of Hashimoto thyroiditis—clinical, gross and histopathological 
A Comprehensive Approach to Thyroid Swellings: Clinical, Sonological, Cytological and Histopathological Correlation

Table 2: The cytological and histological findings in patients with satisfactory aspirates who underwent surgery (70 patients)

\begin{tabular}{|c|c|c|c|c|c|c|}
\hline Nature of the swelling & $\begin{array}{l}\text { Clinical/ } \\
\text { sonological } \\
\text { diagnosis } \\
\end{array}$ & $\begin{array}{l}\text { Cytological } \\
\text { diagnosis }\end{array}$ & $\begin{array}{l}\text { No. of cases } \\
\text { operated }\end{array}$ & $\begin{array}{l}\text { Histo- } \\
\text { pathological } \\
\text { diagnosis }\end{array}$ & Concurrent & $\begin{array}{l}\text { Non- } \\
\text { concurrent }\end{array}$ \\
\hline \multirow{6}{*}{ Diffuse swelling (39) } & \multirow[t]{2}{*}{ Colloid goiter (20) } & Colloid goiter (18) & 5 & Colloid goiter (5) & 5 & - \\
\hline & & \begin{tabular}{|l|} 
Lymphocytic \\
thyroiditis (2) \\
\end{tabular} & - & - & - & - \\
\hline & \multirow{4}{*}{ Thyroiditis (19) } & Colloid goiter (3) & - & - & - & - \\
\hline & & $\begin{array}{l}\text { Lymphocytic } \\
\text { thyroiditis (13) }\end{array}$ & 5 & $\begin{array}{l}\text { Lymphocytic } \\
\text { thyroiditis (5) }\end{array}$ & 5 & - \\
\hline & & $\begin{array}{l}\text { Suspicious of Hürthle } \\
\text { cell neoplasm (2) } \\
\end{array}$ & 2 & $\begin{array}{l}\text { Lymphocytic } \\
\text { thyroiditis (2) }\end{array}$ & - & 2 \\
\hline & & $\begin{array}{l}\text { De Quervain's } \\
\text { thyroiditis (1) } \\
\end{array}$ & - & - & - & - \\
\hline \multirow{4}{*}{ Multinodular (58) } & \multirow{4}{*}{$\begin{array}{l}\text { MNG, MNG with } \\
2^{\circ} \text { symptoms, } \\
\text { MNG, ?do (58) }\end{array}$} & \multirow[t]{2}{*}{ MNG (35) } & \multirow[t]{2}{*}{30} & MNG (27) & 27 & - \\
\hline & & & & \begin{tabular}{|l|} 
Follicular \\
adenoma (3)
\end{tabular} & - & 3 \\
\hline & & \begin{tabular}{|l|} 
MNG with \\
adenomatous \\
hyperplasia (20) \\
\end{tabular} & 14 & MNG (14) & 14 & - \\
\hline & & $\begin{array}{l}\text { MNG + suspicious of } \\
\text { follicular neoplasm (3) }\end{array}$ & 3 & $\begin{array}{l}\text { Follicular } \\
\text { adenoma (3) }\end{array}$ & 3 & - \\
\hline \multirow{4}{*}{ Solitary nodule (6) } & \multirow{4}{*}{$\begin{array}{l}\text { Follicular } \\
\text { neoplasm (6) }\end{array}$} & MNG (2) & - & - & - & - \\
\hline & & \multirow[t]{2}{*}{$\begin{array}{l}\text { Follicular } \\
\text { neoplasm (3) }\end{array}$} & \multirow[t]{2}{*}{3} & \begin{tabular}{|l|} 
Follicular \\
adenoma (2)
\end{tabular} & 2 & - \\
\hline & & & & MNG (1) & - & 1 \\
\hline & & \begin{tabular}{|l|} 
Hürthle cell \\
neoplasm (1)
\end{tabular} & 1 & MNG (1) & - & 1 \\
\hline \multirow{4}{*}{$\begin{array}{l}\text { Diffuse irregular } \\
\text { swelling (7) }\end{array}$} & \multirow{4}{*}{$\begin{array}{l}\text { Suspicious of } \\
\text { malignancy (7) }\end{array}$} & \multirow[t]{2}{*}{$\begin{array}{l}\text { Follicular } \\
\text { neoplasm (2) }\end{array}$} & \multirow[t]{2}{*}{2} & $\begin{array}{l}\text { Follicular } \\
\text { carcinoma (1) }\end{array}$ & 1 & - \\
\hline & & & & $\begin{array}{l}\text { Follicular variant } \\
\text { of PTC (1) }\end{array}$ & - & 1 \\
\hline & & $\begin{array}{l}\text { Suspicious of } \\
\text { PTC (1) }\end{array}$ & 1 & PTC (1) & 1 & - \\
\hline & & $\begin{array}{l}\text { Suggestive of } \\
\text { PTC (4) }\end{array}$ & 4 & PTC (4) & 4 & - \\
\hline
\end{tabular}

Table 3: The accuracy of FNAC was analyzed, first for the detection of malignancy and second for the detection of neoplasia

\begin{tabular}{|c|c|c|c|c|c|}
\hline FNAC diagnosis & $\begin{array}{l}\text { Total no. of } \\
\text { FNAC cases }\end{array}$ & $\begin{array}{l}\text { No. of cases with } \\
\text { surgical biopsy }\end{array}$ & $\begin{array}{l}\text { Correct cytological } \\
\text { diagnosis }\end{array}$ & False positive & False negative \\
\hline Non-neoplastic & 94 & 54 & $51(\mathrm{TN})$ & - & 3 \\
\hline Neoplastic & 16 & 16 & 11 (TP) & 5 & - \\
\hline
\end{tabular}

is low, forming 0.5 to $1 \%$ of all cancers and 3.3 to $17 \%$ of all thyroid diseases. ${ }^{1}$ Ten percent of thyroid swellings proved to be malignant in our study. Majority of thyroid cancers occur in euthyroid individuals, often as asymptomatic nodule. ${ }^{4}$ Single nodules are about four times more common in women than in men and this incidence increases throughout life. Benign neoplasms outnumber thyroid carcinomas by a ratio of nearly 10:11. In our study, ratio of benign to malignant lesions was 9:1.

The aim of preoperative investigations should therefore be to distinguish neoplastic from non neoplastic lesions. Ultrasound has been the standard for imaging of the thyroid gland for many years and is the first line recommended imaging modality for thyroid nodules and can differentiate cysts from cystic degeneration in an adenoma, solid tumors from multinodular goiter and also detects the presence of thyroiditis with greater than $90 \%$ accuracy. ${ }^{5,6}$ It was also used to access the extension of swelling, adhesions and adherence.

A selective surgical policy is clearly desirable and FNAC is being increasingly used as its basis. The decision to operate was based on clinical criteria (age, sex, texture of cytology). The success of FNA depends upon several important factors including aspirator, cytological and clinical information in the context of an individual patient. In mixed, solid, or difficult to palpate lesions, ultrasound guided aspiration technique is clearly superior to palpation guided aspiration. ${ }^{7}$ 
In our study, sensitivity of FNAC was $78.5 \%$, specificity was $91.07 \%$, positive predictive value was $68.75 \%$, negative predictive value was $94.44 \%$ and diagnostic accuracy of FNAC was $88.50 \%$, which is comparable to breast FNACs, in which sensitivities range from 43.8 to $95 \%$, specificities from 89.8 to $100 \%$, positive predictive values from 76.2 to $100 \%$ and negative predictive values from 46.3 to $98.8 \%{ }^{8}$

In our series when FNAC was compared with the initial clinical diagnosis based on history and clinical examination of the patient, it represented no improvement on the original clinical diagnosis of multinodular goiters. Therefore, it can only be considered as an additional tool in these cases. On the other hand, it represented an improvement in the diagnosis of thyroiditis and malignancy in our patients.

\section{CONCLUSION}

Diverse symptoms of thyroid diseases and asymptomatic thyroid swellings present a great challenge in the diagnosis of thyroid swellings. Ultrasonography and fine needle aspiration cytology are valuable tools in assessing the need for surgical intervention in thyroid swellings. USG guided aspiration will certainly enhance the cytological yield and increase diagnostic accuracy.

\section{REFERENCES}

1. Mackenzie EJ, Mortimer RH. Thyroid nodules and thyroid cancer. Med J Aust 2004;180:242-247.

2. Jackson IMD, Thomson JA. The relationship of carcinoma to the single thyroid nodule. Br J Surg 1967;54:1007-1009.

3. Giuffrida D, Gharib H. Controversies in the management of cold, hot and occult nodules. Am J Med 1995;99:642-650.

4. Harvey HK. Diagnosis and management of the thyroid nodule. Otolaryngologic Clinics of North America 1990;23(2):303-336.

5. Cooper DS, Doherty GM, Haugen BR, et al. Revised American Thyroid Association management guidelines for patients with thyroid nodules and differentiated thyroid cancer. Thyroid 2009;19:1167-1214.

6. Rosen IB, Walfish PG, Miskin M. The application of ultrasound to the study of thyroid enlargement: management of 450 cases. Arch Surg 1975;110:940-944.

7. Robinson IA, Cozens NJ. Does a joint ultrasound-guided cytology clinic optimize the cytological evaluation of head and neck masses? Clin Radiol 1999;54:312-316.

8. Cangiarella J, Simsi A. Breast, Orell and Sterrett's Fine Needle Aspiration Cytology. Chapter 7, 5th ed. Churchill Livingstone Elsevier. 2012. p. 156-209. 